\title{
The Effect Upon Micrococcus violagabriellae of Short-Term Exposure to Ultraviolet Light
}

\author{
By J. I. PAYNE AND J. N. CAMPBELL \\ Departments of Bacteriology and Microbiology, University of Alberta, \\ Edmonton, Alberta, Canada
}

(Received 2 September 1964)

\begin{abstract}
SUMMARY
The presence of inorganic or organic iron in the growth medium induces the production of a reddish-violet pigment in Micrococcus violagabriellae. This pigment protects the organism against short exposures to ultraviolet (u.v.) radiation of wavelength below $300 \mathrm{~m} \mu$. The presence of iron also increases the degree of recovery of the normally white organism after such irradiation. Anaerobic growth renders both the red and the white micrococci more resistant to damage by u.v. radiation. However, the addition of nitrate, an alternative to oxygen as a terminal electron acceptor, restores the u.v. sensitivity of these micrococci to that of aerobically grown organisms. It is suggested that the initial site of u.v. irradiation damage is extranuclear and involves one or more cytochrome-linked systems, and that it is within this system(s) that the iron functions both as a radiationprotective and as a restorative agent.
\end{abstract}

\section{INTRODUCTION}

The significance of bacterial pigments as radiation-protective agents has been commented on by several workers for different types of bacteria, e.g. photosynthetic (Sistrom, Griffiths \& Stanier, 1956), non-photosynthetic (Mathews \& Sistrom, 1959) and halophilic (Dundas \& Larsen, 1962). Studies of the radiation-protection of bacteria attributable to pigment have of necessity been comparisons between pigmented wild-type organisms and non-pigmented mutants. For example, Duggan, Anderson \& Elliker (1963) reported that decrease of pigmentation in their strain Rw of Micrococcus radiodurans was correlated with an increase of sensitivity to $\gamma$-radiation. In such comparisons genetic events which govern functions other than pigment production may also be involved. Pigment formation induced by some simple means not involving mutation might be of value in elucidating the mechanism of radiation-sensitivity. Studies along these lines have been made by Cohen-Bazire \& Stanier (1958) and Fuller \& Anderson (1958) who used diphenylamine to inhibit carotenoid synthesis in the photosynthetic bacterium Rhodopseudomonas spheroides. Such inhibition increased the sensitivity of the organisms to the lethal effect of visible light. A reversible system was involved since removal of diphenylamine allowed carotenoid synthesis to resume.

The presence of ferric and/or ferrous ions in growth media induces the production of a reddish-violet pigment in the otherwise white bacterium Micrococcus violagabriellae (Campbell, unpublished results, 1957; Cassingena, Ortali \& Milazzo, 1960). The ready alteration of pigment production in this organism without the complications 
of mutation thus provides a unique system for the study of the effects of the presence or absence of pigment on sensitivity to radiation. Accordingly, we took advantage of this system to compare the effects of u.v. irradiation on red-pigmented and white organisms in the hope that such a comparison might furnish information about the site of irradiation damage.

\section{METHODS}

Organism. The organism used was Micrococcus violagabriellae, isolated originally by Castellani (1955), and obtained from the culture collection of the American Meat Institute Foundation, Chicago, Illinois, U.S.A.

Media. (a) Basal medium (g./l. distilled water): Casamino acids (Difco), 10; yeast extract (Difco), $0 \cdot 3$; cysteine, $0 \cdot 1$; tryptophan, $0 \cdot 1$; asparagine, $0 \cdot 1$; sodium citrate, 5 ; glucose, $5 ; \mathrm{KH}_{2} \mathrm{PO}_{4}, 5 ; \mathrm{NaCl}, 5 ; \mathrm{MgSO}_{4} .7 \mathrm{H}_{2} \mathrm{O}, 0 \cdot 8 ; \mathrm{MnCl}_{2} .4 \mathrm{H}_{2} \mathrm{O}, 0 \cdot 14 ; \operatorname{agar}(\mathrm{Difco})$, 15; $\mathrm{FeCl}_{3}$ (when present), $0 \cdot 1$.

(b) Trypticase soy agar (BBL) $+\left(\right.$ g./1. medium): glucose, $2 \cdot 5 ; \mathrm{FeCl}_{3}$ (when present), $0 \cdot 1$.

Other substances were added as indicated in the text; the media were adjusted to $\mathrm{pH} \mathbf{7 \cdot 2}$ before autoclaving $\left(120^{\circ}, 20 \mathrm{~min}\right.$.) Organisms were grown aerobically, or anaerobically $\left(95 \%(\mathrm{v} / \mathrm{v}) \mathrm{N}_{2}+5 \%(\mathrm{v} / \mathrm{v}) \mathrm{CO}_{2}\right.$ atmosphere with reduced methylene blue as indicator of anaerobiosis.)

The incubation temperature was always $30^{\circ}$.

Plating techniques. The problem of clumping, which affects viable counts of micrococci, was overcome as follows; $18 \mathrm{hr}$ organisms were removed from solid media with sterile $0.03 \mathrm{M}$-phosphate buffer ( $\mathrm{pH} 7 \cdot 2$ ), washed and resuspended in buffer. The suspension was centrifuged for $15 \mathrm{~min}$. at $1000 \mathrm{rev} . / \mathrm{min}$. to sediment clumped cocci. Samples were removed from the upper regions of the tubes and added to sterile buffer to yield a turbidity reading of 1.0 on a Spectronic 20 colorimeter (Bausch \& Lomb) (equivalent to $4 \times 10^{8}$ cocci $/ \mathrm{ml}$.). Phase microscopic examination showed that this suspension consisted nearly exclusively of single cocci. Serial 10-fold dilutions of this suspension were then made to $1 / 10^{7}$ and $1.0 \mathrm{ml}$. samples of the desired dilutions were spread on plates of appropriate media; all platings were made in triplicate. Plates were incubated at $30^{\circ}$ for $48 \mathrm{hr}$ at which time the colonies were counted. By this method it was possible to obtain reproducibility within $10 \%$, and this value was taken to be the maximum permissible degree of variation.

Irradiation techniques. (a) Ultraviolet radiation. A $15 \mathrm{~W}$. germicidal lamp (General Electric) giving a minimum of $90 \%$ emission at $260 \mathrm{~m} \mu$ at a distance of $40 \mathrm{~cm}$. from the surface to be irradiated was the source of ultraviolet (u.v.) radiation. This arrangement yielded a dosage of $102 \mathrm{ergs} / \mathrm{sec} . / \mathrm{cm}^{2}$. at the irradiated surface as measured by a model SM 200 U.V. click meter (Westinghouse Electric Corp., Bloomfield, N.J., U.S.A.). Routinely a 5 sec. exposure was given because it killed about $70 \%$ of the cocci of the most sensitive system tested and hence permitted detection of alterations in sensitivity or resistance. Longer exposure times were used, as indicated, to obtain mortality curves, or in those experiments which used filters when the exposure time was increased to $7 \mathrm{sec}$. to compensate for energy loss in the filter. 
Cocci were prepared for irradiation in one of two ways. The buffered suspension of washed centrifuged cocci was placed in a flat bottomed Petri dish to give a layer of suspension not more than $2 \mathrm{~mm}$. thick and the plate gently agitated during irradiation. Dilutions were then made, plated and the colonies counted. In other experiments dilutions of the original suspension were plated and irradiated on the surface of the medium.

In experiments which required the exclusion of far u.v. wavelengths $8 \times 8 \times$ $\mathbf{0 . 4} \mathrm{cm}$. glass filters (Corning Glass Co.) were placed in an opaque frame and mounted $1 \mathrm{~cm}$. from the irradiated agar surface. The characteristics of these filters are summarized in Table 1.

\section{Table 1. Transmittance characteristics of u.v. filters}

\begin{tabular}{|c|c|c|c|}
\hline Filter & $\begin{array}{c}\text { Transmitting } \\
\text { (range } \mathrm{m} \mu \text { ) }\end{array}$ & $\begin{array}{c}\lambda_{\max .}{ }^{*} \\
(\mathrm{~m} \mu)\end{array}$ & $\begin{array}{l}\% \text { of input } \\
\text { transmitted } \\
\text { at } \lambda_{\max }\end{array}$ \\
\hline $7-51$ & $\begin{array}{l}295-425 \\
690-\end{array}$ & $\begin{array}{l}365 \\
750\end{array}$ & $\begin{array}{l}80 \\
40\end{array}$ \\
\hline $7-59$ & $\begin{array}{l}290-490 \\
690-\end{array}$ & $\begin{array}{l}360 \\
750\end{array}$ & $\begin{array}{l}90 \\
40\end{array}$ \\
\hline
\end{tabular}

Cocci were irradiated anaerobically in a gas tight $100 \times 65 \times 50 \mathrm{~cm}$. glass-fronted inoculating hood fitted with long-sleeved rubber gloves. Plates to be irradiated were placed in the hood some time before irradiation and a continuous flow of $\mathbf{N}_{2}$ (de-oxygenated by passage through alkaline pyrogallol) was maintained through the hood during irradiation. Reduced methylene blue again served as the test for anaerobiosis.

(b) Visible light. Studies of the lethal effect of visible light used a $500 \mathrm{~W}$ tungsten photoflood lamp (General Electric). Organisms to be illuminated were placed in glass tubes and immersed in a glass-walled constant temperature ice-water bath to prevent heating. Samples were placed $37 \mathrm{~cm}$. from the light source and agitated periodically during illumination. In all cases non-illuminated control tubes wrapped in aluminium foil were held alongside the illuminated samples. Dilutions and plating were carried out as described.

Nitrate reduction. The accumulation of nitrite in culture media was measured by using the sulphanilic acid $+\alpha$-naphthylamine spot test (Pelczar, 1957); the colour development was estimated visually.

\section{RESULTS}

The production of the characteristic reddish-violet pigment of Micrococcus violagabriellae is dependent on the presence of oxygen and inorganic iron; the iron is incorporated into the pigment molecule (Payne \& Campbell, 1962, 1963). The effect of iron on the ability of the micrococci to withstand u.v.-irradiation damage was measured. The results (Table 2) showed that $74 \%$ of the cocci grown in the absence of iron (i.e. white cocci) were killed by 5 sec. exposure to u.v. irradiation, whereas cocci grown in media containing iron (i.e. red cocci), suffered only a $28 \%$ mortality under identical conditions. Furthermore, the presence of iron in the post- 
irradiation medium decreased the lethality of the u.v. irradiation for both red and white cocci, indicating that iron not only protected the cocci but also aided recovery from irradiation damage.

Optimal protection against u.v.-radiation damage was achieved by using $\mathrm{FeCl}_{3}$ (100 $\mu \mathrm{g} . / \mathrm{ml}$.) in the medium. This concentration was also optimal for pigment production and, since higher concentrations of iron neither increased resistance to u.v. irradiation nor increased the amount of pigment, this concentration was used routinely thereafter. No concentration of iron used affected the viability of unirradiated control organisms.

Table 2. The effect of inorganic iron upon pigment production and resistance to u.v. irradiation

$\mathrm{FeCl}_{3}$ in
inoculum
medium
(mg./ml.)
0
0
100
100

100

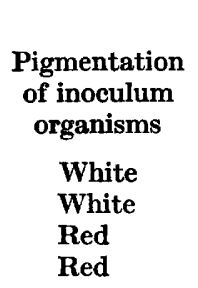

Survivors
$(\%)$
$26 \cdot 0$
$61 \cdot 3$
$71 \cdot 6$
$81 \cdot 6$

Table 3. The influence of type of iron-containing compound on the resistance of Micrococcus violagabriellae to u.v. radiation for 5 sec.

\begin{tabular}{|c|c|c|c|c|c|c|}
\hline \multirow{2}{*}{\multicolumn{2}{|c|}{ Inoculum }} & \multicolumn{5}{|c|}{ Survivors on various post-irradiation media (\%) } \\
\hline & & \multirow[b]{2}{*}{$\mathbf{0}$} & \multirow[b]{2}{*}{$\mathrm{FeCl}_{3}^{*}$} & \multicolumn{2}{|c|}{ Basal + } & \multirow[b]{2}{*}{ Haemins } \\
\hline $\begin{array}{l}\text { Growth } \\
\text { medium }\end{array}$ & $\underset{\text { Pion }}{\text { Pigmenta- }}$ & & & HB. $\dagger$ & Dial. Hb. & \\
\hline \multicolumn{7}{|l|}{ Basal + } \\
\hline $\mathbf{0}$ & White & $\mathbf{2 5 \cdot 5}$ & $63 \cdot 1$ & $\mathbf{8 2} \cdot 0$ & $71 \cdot 0$ & $76 \cdot 4$ \\
\hline $\mathrm{FeCl}_{3}^{*}$ & Red & $71 \cdot 4$ & $80 \cdot 1$ & $87 \cdot 9$ & $\mathbf{7 7} \cdot 0$ & $81 \cdot 0$ \\
\hline Hb.† & White & $77 \cdot 3$ & $89 \cdot 7$ & 一 & - & - \\
\hline Dial. Hb. $\ddagger$ & White & $63 \cdot 4$ & $84 \cdot 8$ & - & - & - \\
\hline Haeming & White & $76 \cdot 7$ & $86 \cdot 2$ & - & - & - \\
\hline
\end{tabular}

* $\mathrm{FeCl}_{3}=100 \mu \mathrm{g} . / \mathrm{ml}$; + HB. = Haemoglobin, $6 \mathrm{mg} . / \mathrm{ml} . ; \ddagger$ Dial. Hb. = Dialysed haemoglobin, $6 \mathrm{mg} . / \mathrm{ml}$.; \& Haemin $=2.5 \mathrm{mg} . / \mathrm{ml}$.

To ascertain the dependence upon type of iron, various organic sources of iron were substituted for $\mathrm{FeCl}_{3}$, to yield equivalent final concentrations of $\mathrm{Fe}$. The results (Table 3) showed that although the organic iron sources did not support pigment formation they did confer a degree of protection to u.v. irradiation comparable to that obtained from inorganic iron.

The lethal effect of brief exposure to u.v. radiation might result from damage to some intracellular mechanism or from some irradiation-induced alteration to the extracellular environment which rendered it toxic. Accordingly, experiments were made in which red and white cocci were placed on duplicate sets of media, one half of which had been irradiated for 10 sec. immediately before inoculation. The inoculated plates then received a further 5 sec. irradiation. The results (Table 4) showed that pre-irradiation of the media had no demonstrable effect on survival.

Both red and white cocci were observed to produce catalase under aerobic 
conditions of growth, as evidenced by the evolution of gas upon exposure of the cocci to $3 \% \mathrm{H}_{2} \mathrm{O}_{2}$ solution.

It was observed that when white cocci (the most sensitive system) were u.v. irradiated in buffer, and then plated on iron-free medium, only $15.5 \%$ survived, compared with $36 \%$ if the organisms were plated on iron-containing medium. These results lead to two conclusions: First, iron need not be present at the moment of irradiation in order to effect a modification in sensitivity, but will still function when it is supplied shortly thereafter. For iron to enhance recovery from the u.v.-radiation damage incurred under these conditions, the cocci must be exposed to iron within approximately $5 \mathrm{~min}$. after irradiation. When this time interval was prolonged the ability of the iron to increase survival rates diminished, presumably as the u.v.-induced lesion(s) became irreversible. Thus, the iron in the post-irradiation medium functioned by abetting repair of u.v.-damaged mechanism(s) and not as a passive protective agent. Secondly, the presence or absence of other medium constituents at the time of irradiation did not affect the behaviour of the cocci under these conditions. Hence the technique of u.v.-irradiating cocci on the surface of the growth medium is valid.

Table 4. The effect of u.v.-irradiation of the medium, before inoculation of Micrococcus violagabriellae, on resistance to subsequent u.v. irradiation

\begin{tabular}{|c|c|c|c|}
\hline Inoculum & $\begin{array}{c}\text { Post-irradiation } \\
\text { media }\end{array}$ & $\begin{array}{l}\text { Pre-inoculation } \\
\text { irradiation of } \\
\text { medium } \\
\text { (sec.) }\end{array}$ & $\begin{array}{c}\text { Survivors } \\
(\%)\end{array}$ \\
\hline \multirow{11}{*}{$\begin{array}{l}\text { White } \\
\text { micrococci }\end{array}$} & Basal + & & \\
\hline & 0 & 0 & $53 \cdot 0$ \\
\hline & & 10 & $54 \cdot 5$ \\
\hline & $\mathrm{FeCl}_{3}{ }^{*}$ & 0 & $75 \cdot 0$ \\
\hline & & 10 & $73 \cdot 4$ \\
\hline & Hb. $\dagger$ & 0 & $82 \cdot 8$ \\
\hline & & 10 & $81 \cdot 0$ \\
\hline & Dial. Hb. & 0 & $78 \cdot 0$ \\
\hline & & 10 & $71 \cdot 6$ \\
\hline & Haemin§ & 0 & $72 \cdot 0$ \\
\hline & & 10 & $69 \cdot 1$ \\
\hline \multirow{10}{*}{$\begin{array}{l}\text { Red } \\
\text { micrococci }\end{array}$} & $\mathbf{0}$ & $\mathbf{0}$ & $81 \cdot 4$ \\
\hline & & 10 & $78 \cdot 8$ \\
\hline & $\mathrm{FeCl}_{3}$ & $\mathbf{0}$ & $80 \cdot 1$ \\
\hline & & 10 & $82 \cdot 6$ \\
\hline & Hb. & 0 & 87.9 \\
\hline & & 10 & $89 \cdot 8$ \\
\hline & Dial. $\mathbf{H b}$. & 0 & $77 \cdot 0$ \\
\hline & & 10 & $75 \cdot 4$ \\
\hline & Haemin & 0 & $81 \cdot 0$ \\
\hline & & 10 & $85 \cdot 0$ \\
\hline
\end{tabular}

* $\mathrm{FeCl}_{3}=0 \cdot 1 \mathrm{mg} . / \mathrm{ml}$; $\dagger$ Hb. = haemoglobin, $6 \mathrm{mg} . / \mathrm{ml}$; $\ddagger$ Dial. Hb. = dialysed haemoglobin, $6 \mathrm{mg} . / \mathrm{ml}$; ; \& Haemin $=2.5 \mathrm{mg} . / \mathrm{ml}$.

The report of Kashket \& Brodie (1962) on the lethal effects of long-term exposure of Escherichia coli and Pseudomonas aeruginosa to near-u.v. radiation ( $360 \mathrm{~m} \mu$ ) made it imperative to test the effects of these longer wavelengths upon the Micrococcus 
violagabriellae system. This was done in two ways: (i) by using a tungsten light source; (ii) by using the source of u.v. radiation but with appropriate filters.

Repeated attempts to show inactivation of the micrococci by illumination with intense visible light for periods up to $2 \mathrm{hr}$ were unsuccessful. The survival rate of cocci in buffer under illumination was in all cases the same as that of the cocci in the dark; and the presence or absence of red pigment and/or exogenous iron had no modifying effect. No photo-reactivation of Micrococcus violagabriellae after short term exposure to u.v.-radiation was observed. Table 5 shows that when cocci were u.v. irradiated for $5 \mathrm{sec}$. and then exposed to intense visible light for $\mathbf{3 0} \mathrm{min}$. their

Table 5. Effect of visible light upon u.v.-irradiated Micrococcus violagabriellae

\begin{tabular}{|c|c|c|c|c|}
\hline Organism & $\begin{array}{l}\text { Post-irradiation } \\
\text { media }\end{array}$ & $\begin{array}{l}\text { Time of } \\
\text { exposure } \\
\text { to u.v. } \\
\text { radiation } \\
\text { (sec.) }\end{array}$ & $\begin{array}{l}\text { T'ime of } \\
\text { exposure to } \\
\text { visible light } \\
\text { (min.) }\end{array}$ & $\begin{array}{c}\text { Survivors } \\
(\%)\end{array}$ \\
\hline \multirow[t]{4}{*}{ White } & Basal & 5 & $\overline{20}$ & $37 \cdot 3$ \\
\hline & & 5 & 30 & $\mathbf{3 4} \cdot 0$ \\
\hline & Basal $+\mathrm{Fe}$ & 5 & - & 68.0 \\
\hline & & 5 & 30 & $65 \cdot 6$ \\
\hline \multirow[t]{4}{*}{ Red } & Basal & 5 & - & 47.9 \\
\hline & & 5 & 30 & $53 \cdot 5$ \\
\hline & Basal + Fe & 5 & - & 68.5 \\
\hline & & 5 & 30 & 64.8 \\
\hline
\end{tabular}

Table 6. Effect of elimination of short wavelengths on lethal effect of u.v. radiation on Micrococcus violagabriellae

$\begin{array}{cclr}\text { Organisms } & \begin{array}{c}\text { Post-irradiation } \\ \text { media }\end{array} & \begin{array}{l}\text { Irradiation } \\ \text { conditions }\end{array} & \begin{array}{c}\text { Survivors } \\ (\%)\end{array} \\ \text { White } & \text { Basal } & \text { No filter } & \mathbf{3 4 \cdot 0} \\ & & \text { Filter 1 } & 94 \cdot 5 \\ & & \text { Filter 2 } & 101 \cdot 5 \\ & \text { Basal + Fe } & \text { No filter } & 54 \cdot 0 \\ & & \text { Filter 1 } & 94 \cdot 7 \\ \text { Red } & \text { Bilter 2 } & \mathbf{9 8 \cdot 0} \\ & & \text { No filter } & 64 \cdot 2 \\ & & \text { Filter 1 } & 101 \cdot 4 \\ & & \text { Filter 2 } & 101 \cdot 0 \\ & \text { Basal }+ \text { Fe } & \text { No filter } & 84 \cdot 0 \\ & & \text { Filter 1 } & 100 \cdot 8 \\ & & \text { Filter 2 } & 96 \cdot 5\end{array}$

survival was not significantly different from that of cocci held in the dark under identical conditions after exposure to u.v. radiation. This lack of significant photoreactivation serves to differentiate the effects of short-term exposure to u.v. radiation seen in these experiments with $M$. violagabriellae, from those observed with other organisms and leads to the consideration of a possible extranuclear site of damage as one of the initial sites of u.v. action.

Table 6 shows the results of an experiment in which the response of micrococci to 5 sec. exposure to unfiltered u.v. radiation was compared to that of micrococci which 
received an equivalent dose of u.v. radiation of wavelengths $>300 \mathrm{~m} \mu$ from the same source (the wavelengths below $300 \mathrm{~m} \mu$ being eliminated by filters). The presence of pigment and/or exogenous iron again exerted no modifying effect. Consequently the observed lethal effect results from wavelengths below $300 \mathrm{~m} \mu$.

Since atmospheric $\mathrm{O}_{2}$ is required by Micrococcus violagabriellae for pigment synthesis, the role that $\mathrm{O}_{2}$ might play in the sensitivity of this organism to u.v. radiation was examined. Aerobically-grown and anaerobically-grown micrococci were compared with respect to their sensitivity to u.v. irradiation for 5 sec., and the effect of post-irradiation anaerobiosis was studied. The irradiation procedure itself was done in the presence of air. The results (Table 7) show that cocci grown anaerobically in the absence of iron were about 2.5 times more resistant to u.v. radiation than were their aerobically grown counterparts. Addition of iron to the pre-irradiation medium decreased this difference in sensitivity to some 1.5 times, but the increased resistance conferred by anaerobic growth was still evident. The substitution of organic iron sources for inorganic ones did not alter this observation. Anaerobiosis after u.v. irradiation had no effect on survival in any of these systems.

Table 7. The effect of anaerobiosis on resistance of

Micrococcus violagabriellae to u.v. irradiation

\begin{tabular}{|c|c|c|c|c|}
\hline \multirow{3}{*}{$\begin{array}{l}\text { Pre-irradiation } \\
\text { incubation }\end{array}$} & & & \multicolumn{2}{|c|}{ Survivors (\%) } \\
\hline & \multicolumn{2}{|c|}{ Post-irradiation } & \multirow{2}{*}{$\begin{array}{l}\text { White } \\
\text { pigmented } \\
\text { cells }\end{array}$} & \multirow{2}{*}{$\begin{array}{c}\text { Red } \\
\text { pigmented } \\
\text { cells }\end{array}$} \\
\hline & Media & incubation & & \\
\hline \multirow[t]{9}{*}{ Aerobic } & o & $\begin{array}{l}\text { Aerobic } \\
\text { Anaerobic }\end{array}$ & $\begin{array}{l}30 \cdot 8 \\
32.9\end{array}$ & $\begin{array}{l}68 \cdot 9 \\
63 \cdot 1\end{array}$ \\
\hline & \multirow[t]{2}{*}{$\mathrm{FeCl}_{3} *$} & Aerobic & $51 \cdot 5$ & $82 \cdot 0$ \\
\hline & & Anaerobic & $52 \cdot 4$ & $83 \cdot 1$ \\
\hline & \multirow[t]{2}{*}{ Hb. $†$} & Aerobic & $69 \cdot 3$ & $88 \cdot 3$ \\
\hline & & Anaerobic & $72 \cdot 2$ & $82 \cdot 6$ \\
\hline & \multirow{2}{*}{ Dial. Hb. $\ddagger$} & Aerobic & $70 \cdot 3$ & $85 \cdot 6$ \\
\hline & & Anaerobic & $80 \cdot 0$ & $88 \cdot 0$ \\
\hline & \multirow[t]{2}{*}{ Haemin§ } & Aerobic & $60 \cdot 8$ & $83 \cdot 5$ \\
\hline & & Anaerobic & $62 \cdot 0$ & $78 \cdot 5$ \\
\hline \multirow[t]{10}{*}{ Anaerobic } & \multirow[t]{2}{*}{$\mathbf{0}$} & Aerobic & $69 \cdot 0$ & $79 \cdot 8$ \\
\hline & & Anaerobic & $62 \cdot 0$ & $78 \cdot 8$ \\
\hline & \multirow[t]{2}{*}{$\mathrm{FeCl}_{3}$} & Aerobic & $81 \cdot 5$ & $90 \cdot 1$ \\
\hline & & Anaerobic & $86 \cdot 1$ & $87 \cdot 8$ \\
\hline & \multirow[t]{2}{*}{ Hb. } & Aerobic & $81 \cdot 1$ & $79 \cdot 9$ \\
\hline & & Anaerobic & $82 \cdot 6$ & $80 \cdot 4$ \\
\hline & \multirow[t]{2}{*}{ Dial. Hb. } & Aerobic & $89 \cdot 0$ & $88 \cdot 7$ \\
\hline & & Anaerobic & $91 \cdot 0$ & $87 \cdot 3$ \\
\hline & \multirow{2}{*}{ Haemin } & Aerobic & $86 \cdot 0$ & $80 \cdot 3$ \\
\hline & & Anaerobic & $78 \cdot 4$ & $81 \cdot 9$ \\
\hline
\end{tabular}

* $\mathrm{FeCl}_{3}=100 \mu \mathrm{g} . / \mathrm{ml}$.; † Hb. = haemoglobin, $6 \mathrm{mg} . / \mathrm{ml} . ; \ddagger$ Dial. Hb. = dialysed haemoglobin, $6 \mathrm{mg} . / \mathrm{ml}$; $\$$ Haemin $=2.5 \mathrm{mg} . / \mathrm{ml}$.

The next question concerned the importance of $\mathrm{O}_{2}$ at the time of exposure of the micrococci to u.v. radiation. Experiments were made wherein cocci from various sources were irradiated in an inoculating hood under de-oxygenated $\mathbf{N}_{2}$ and their sensitivity compared to that of duplicate systems irradiated in air. The results 
(Table 8) indicated that the absence of $\mathrm{O}_{2}$ at the time of irradiation did not alter resistance or ability of the cocci to recover from u.v.-radiation damage.

In summary, the experiments showed that the presence or absence of $\mathbf{O}_{2}$ was effective only during the period of growth of the micrococci immediately before u.v. irradiation. The presence or absence of $\mathrm{O}_{2}$ at, or subsequent to the time of irradiation was immaterial to the ability of the micrococci to withstand or to recover from u.v.-radiation damage.

One role of $\mathrm{O}_{2}$ in the life of these micrococci is as a terminal electron acceptor in aerobic metabolism. The effect of substitution of suitable alternative electron acceptor(s) upon this system was examined. Methylene blue would function in this respect but $\mathrm{KNO}_{3}$ was found to be superior and it was used routinely. Tubes of basal

Table 8. Effect of oxygen on u.v. sensitivity of Micrococcus violagabriellae

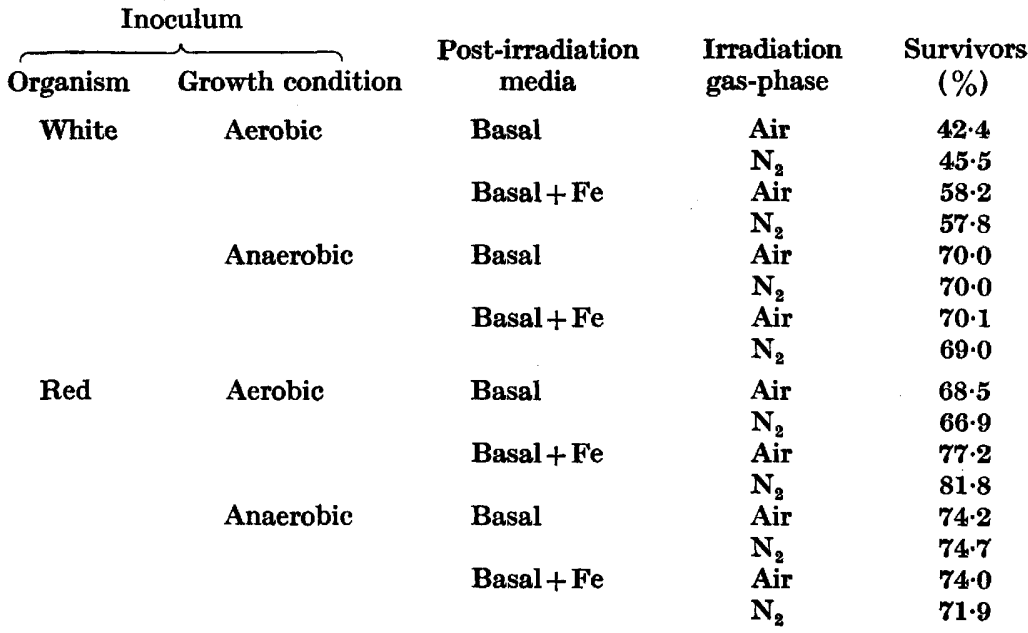

Table 9. Effect of nitrate and/or fluoride on growth and pigment production of Micrococcus violagabriellae

\begin{tabular}{|c|c|c|c|c|}
\hline Growth medium & $\begin{array}{l}\text { Incubation } \\
\text { conditions }\end{array}$ & $\begin{array}{c}\text { Growth response } \\
\text { (absorbance at } \\
600 \mathrm{~m} \mu \text { ) }\end{array}$ & $\begin{array}{l}\text { Accumulation } \\
\text { of nitrite }\end{array}$ & $\begin{array}{c}\text { Production } \\
\text { of red } \\
\text { pigment }\end{array}$ \\
\hline \multicolumn{5}{|l|}{ Basal+ } \\
\hline & Aerobic & $1 \cdot 3$ & - & - \\
\hline & Anaerobic & 0.48 & - & - \\
\hline \multirow{2}{*}{$\mathrm{KNO}_{3}$} & Aerobic & $1 \cdot 2$ & +++ & - \\
\hline & Anaerobic & 0.8 & ++ & - \\
\hline \multirow[t]{2}{*}{$\mathrm{NaF}$} & Aerobic & $1 \cdot 3$ & - & - \\
\hline & Anaerobic & 0.18 & - & - \\
\hline \multirow[t]{2}{*}{$\mathrm{NaF}+\mathrm{KNO}_{3}$} & Aerobic & $1 \cdot 4$ & +++ & - \\
\hline & Anaerobic & 0.9 & ++ & - \\
\hline \multirow[t]{2}{*}{$\mathrm{FeCl}_{3}$} & Aerobic & $1 \cdot 3$ & - & ++++ \\
\hline & Anaerobic & 0.52 & - & - \\
\hline $\mathrm{FeCl}_{3}+\mathrm{KNO}_{3}$ & $\begin{array}{l}\text { Aerobic } \\
\text { Anaerobic }\end{array}$ & $\begin{array}{l}1 \cdot 3 \\
0.75\end{array}$ & $\begin{array}{l}+++ \\
+++\end{array}$ & +++ \\
\hline \multirow[t]{2}{*}{$\mathrm{FeCl}_{3}+\mathrm{NaF}$} & Aerobic & $1 \cdot 28$ & - & ++++ \\
\hline & Anaerobic & $0 \cdot 21$ & - & - \\
\hline \multirow{2}{*}{$\begin{array}{l}\mathrm{FeCl}_{3}+\mathrm{KNO}_{3} \\
+\mathrm{NaF}\end{array}$} & Aerobic & $1 \cdot 3$ & +++ & ++++ \\
\hline & Anaerobic & $0 \cdot 75$ & $+t$ & - \\
\hline
\end{tabular}


medium, with or without $\mathrm{FeCl}_{3}, \mathrm{KNO}_{3}(0.01 \mathrm{M})$, and/or $\mathrm{NaF}(0.01 \mathrm{~m})$ were prepared, inoculated, and incubated aerobically or anaerobically. Growth response and nitrite accumulation were measured. Plates of corresponding solid media were inoculated under identical conditions to check on pigment production which was estimated visually. The results (Table 9) showed that the presence of $0.01 \mathrm{M}-\mathrm{KNO}_{3}$ inhibited neither growth nor pigment production of aerobically grown micrococci. That $\mathrm{NO}_{3}$ - was functional as an electron acceptor was supported by two observations (i) $\mathrm{NO}_{2}^{-}$accumulated aerobically and anaerobically (no evidence was obtained indicating ability of the micrococci to further reduce $\mathrm{NO}_{2}^{-}$); (ii) the stimulation in aerobic growth response which occurred when $\mathrm{NO}_{3}-$ was added to the medium. Sodium fluoride $(0.01 \mathrm{~m})$ functioned as an inhibitor only under anaerobic conditions and this inhibition was completely reversed by the $\mathrm{NO}_{3}^{-}$.

Table 10. Effect of nitrate on u.v. sensitivity of Micrococcus violagabriellae

\begin{tabular}{|c|c|c|c|}
\hline \multicolumn{2}{|c|}{ Inoculum } & \multirow[b]{2}{*}{$\begin{array}{l}\text { Post-irradiation } \\
\text { medium }\end{array}$} & \multirow[b]{2}{*}{$\begin{array}{c}\text { Survivors } \\
(\%)\end{array}$} \\
\hline Growth medium & $\begin{array}{c}\text { Growth } \\
\text { conditions }\end{array}$ & & \\
\hline $\begin{array}{c}\text { Basal }+ \\
0\end{array}$ & $\begin{array}{l}\text { Aerobic } \\
\text { Anaerobic }\end{array}$ & $\begin{array}{l}\text { Basal } \\
\text { Basal + Fe } \\
\text { Basal } \\
\text { Basal + Fe }\end{array}$ & $\begin{array}{l}41 \cdot 6 \\
78 \cdot 7 \\
78 \cdot 1 \\
75 \cdot 2\end{array}$ \\
\hline $\mathrm{Fe}$ & $\begin{array}{l}\text { Aerobic } \\
\text { Anaerobic }\end{array}$ & $\begin{array}{l}\text { Basal } \\
\text { Basal + Fe } \\
\text { Basal } \\
\text { Basal + Fe }\end{array}$ & $\begin{array}{l}\mathbf{7 4 \cdot \cdot 3} \\
\mathbf{9 2 \cdot 2} \cdot 2 \\
\mathbf{8 8 \cdot 2} \\
\mathbf{8 3} \cdot 5\end{array}$ \\
\hline $\mathrm{NO}_{3}$ & $\begin{array}{l}\text { Aerobic } \\
\text { Anaerobic }\end{array}$ & $\begin{array}{l}\text { Basal } \\
\text { Basal + Fe } \\
\text { Basal } \\
\text { Basal + Fe }\end{array}$ & $\begin{array}{l}39 \cdot 1 \\
87 \cdot 9 \\
45 \cdot 5 \\
75 \cdot 1\end{array}$ \\
\hline $\mathrm{Fe}+\mathrm{NO}_{3}$ & $\begin{array}{l}\text { Aerobic } \\
\text { Anaerobic }\end{array}$ & $\begin{array}{l}\text { Basal } \\
\text { Basal + Fe } \\
\text { Basal } \\
\text { Basal + Fe }\end{array}$ & $\begin{array}{l}72 \cdot 6 \\
82 \cdot 0 \\
69 \cdot 9 \\
77 \cdot 6\end{array}$ \\
\hline
\end{tabular}

Having established $\mathrm{NO}_{3}$ - functioned as an alternative electron acceptor, experiments were made to see whether it would further mimic oxygen by restoring u.v. sensitivity to anaerobically-grown micrococci. Table 10 shows the results of such experiments; the effect of iron on sensitivity to u.v. radiation was again evident. Nitrate produced no significant change in the u.v. sensitivity of aerobically-grown micrococci. However, the presence of $\mathrm{NO}_{3}-$ in the medium of micrococci grown in the absence of $\mathrm{O}_{2}$ restored the degree of u.v. sensitivity of these micrococci to that of their aerobically-grown counterparts. This confirmed that $\mathrm{NO}_{3}-$ could substitute for $\mathrm{O}_{2}$ in all regards as an electron acceptor.

Previous work with this organism was concerned with the effect of various inhibitors upon growth and pigment formation (Campbell, Nichols \& Berry, 1964). Table 11 shows the effect on sensitivity to u.v. radiation of adding some of these inhibitors to the growth media. The concentrations used had been found to affect 
the pigment production but not the growth of the organisms. The data from micrococci grown in the absence of iron showed that neither glutathione nor 0 -cresol affected sensitivity or recovery. Ascorbic acid decreased the sensitivity somewhat but did not affect recovery. With micrococci grown in presence of iron, ascorbic acid inhibited pigment production only slightly, with the result that resistance to u.v. radiation was high. Glutathione partially inhibited pigment production and by so doing increased the sensitivity of these micrococci to a value intermediate between those of red and white micrococci. $O$-cresol completely inhibited pigment formation and thereby rendered the micrococci most sensitive to $u$.v. radiation. The correlation between the degree of inhibition of pigment formation and the degree of increase of sensitivity to $u . v$. radiation is apparent. Table 11. Effect of various inhibitors on pigment production and
u.v. sensitivity of Micrococcus violagabriellae Concentration of additions: glutathione, $0.4 \mathrm{mg} . / \mathrm{ml}$; ascorbic acid, $0.8 \mathrm{mg} . / \mathrm{ml}$.;
o-cresol, $1.8 \mathrm{mg} . / \mathrm{ml}$.; $\mathrm{Fe}^{8+}\left(\right.$ as $\left.\mathrm{FeCl}_{3}\right), 0.1 \mathrm{mg} . / \mathrm{ml}$.

\begin{tabular}{|c|c|c|c|}
\hline \multicolumn{2}{|c|}{ Inoculum } & \multirow[b]{2}{*}{$\begin{array}{l}\text { Post-irradiation } \\
\text { medium }\end{array}$} & \multirow[b]{2}{*}{$\begin{array}{c}\text { Survivors } \\
(\%)\end{array}$} \\
\hline Growth medium & $\begin{array}{l}\text { Pigment } \\
\text { formed }\end{array}$ & & \\
\hline \multicolumn{4}{|l|}{ Basal + } \\
\hline $\mathbf{0}$ & White & $\begin{array}{l}\text { Basal } \\
\text { Basal + Fe }\end{array}$ & $\begin{array}{l}48.6 \\
64.5\end{array}$ \\
\hline Glutathione & White & $\begin{array}{l}\text { Basal } \\
\text { Basal }+\mathrm{Fe}\end{array}$ & $\begin{array}{l}49 \cdot 5 \\
70 \cdot 2\end{array}$ \\
\hline Ascorbic acid & White & $\begin{array}{l}\text { Basal } \\
\text { Basal +Fe }\end{array}$ & $\begin{array}{l}59 \cdot 3 \\
80 \cdot 2\end{array}$ \\
\hline o-cresol & White & $\begin{array}{l}\text { Basal } \\
\text { Basal }+\mathrm{Fe}\end{array}$ & $\begin{array}{l}52 \cdot 5 \\
63 \cdot 0\end{array}$ \\
\hline $\mathbf{F e}$ & Red & $\begin{array}{l}\text { Basal } \\
\text { Basal +Fe }\end{array}$ & $\begin{array}{l}75 \cdot 9 \\
91 \cdot 8\end{array}$ \\
\hline $\mathrm{Fe}+$ glutathione & Red & $\begin{array}{l}\text { Basal } \\
\text { Basal + Fe }\end{array}$ & $\begin{array}{l}70 \cdot 0 \\
81 \cdot 8\end{array}$ \\
\hline $\mathrm{Fe}+$ ascorbic acid & Red & $\begin{array}{l}\text { Basal } \\
\text { Basal + Fe }\end{array}$ & $\begin{array}{r}95.6 \\
100.0\end{array}$ \\
\hline $\mathrm{Fe}+$ o-cresol & White & $\begin{array}{l}\text { Basal } \\
\text { Basal + Fe }\end{array}$ & $\begin{array}{l}45 \cdot 5 \\
70 \cdot 0\end{array}$ \\
\hline
\end{tabular}

Preliminary experiments indicated that the modifying influences on sensitivity to u.v. radiation of this organism tended to become less pronounced when the dosage of u.v. radiation was increased. The response of the micrococci to different doses of u.v. radiation (given by different exposure times) was examined. Examples of typical survival curves are given in Fig. 1. These experiments produced curves which compared the effect of: $(a)$ presence or absence of red pigment: $(b)$ presence or absence of iron in the post-irradiation medium; $(c)$ anaerobic or aerobic growth of inoculum; $(d)$ presence or absence of $\mathrm{NO}_{3}-$ in the pre-irradiation medium of anaerobically-grown organisms. In all cases the two-phase curve shown in Fig. 1 was obtained. Furthermore, the differences in behaviour occurred in the response to u.v. irradiation for 5-10 sec. After this time the survival curves became parallel in all cases. This is seen by comparing the slopes of the curves in Fig. 1 from 10 sec. onward; curve $1,1 \cdot 44$ : curve $2,1 \cdot 42$ : curve $3,1 \cdot 20$ : curve $4,1 \cdot 26$. 


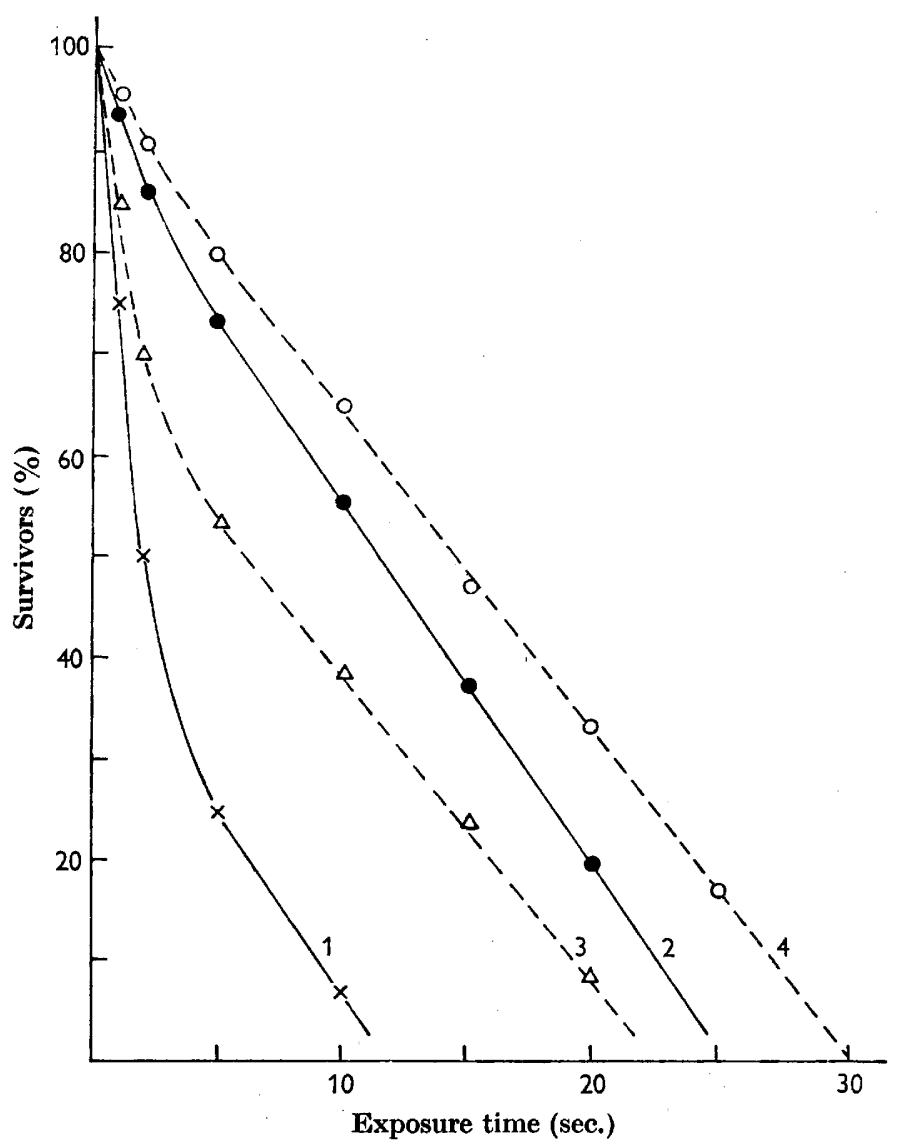

Fig. 1. Effect of increasing time of exposure to u.v. radiation on viability of Micrococcus violagabriellae. Curve $1(x-x)$, white micrococci on iron-free post-irradiation medium; Curve 2 ( -0$)$, red micrococci on iron-free post-irradiation medium; Curve 3 $(\triangle--\triangle)$, white micrococci on iron-containing post-irradiation medium; Curve 4 $(\mathrm{O}-\mathrm{O})$, red micrococci on iron-containing post-irradiation medium.

\section{DISCUSSION}

The data showing the protective effect of the red pigment, and the modification of this effect with inhibitors, connect the red pigment, or its formation, with the site of u.v.-radiation damage in this organism. That the lethal effect of short-term u.v. radiation involves an iron dependent system is shown by the fact that protection is conferred not only by the presence of iron containing pigment which has been identified as pulcherrimin (Campbell et al. 1964) but also by sources of iron that do not support pigment production.

The results from the use of the inhibitors permit speculation about this system. For micrococci growing in the absence of iron, hence not synthesizing red pigment, glutathione had no effect on sensitivity to u.v. radiation which suggests that a sulphydryl system was not involved. $O$-cresol similarly had no effect on nonpigmented micrococci. Both of these substances can affect sensitivity to u.v. 
radiation only under conditions where their presence depresses the amount of pigment synthesized, and hence the amount of iron complexed by the organisms. Ascorbic acid decreased the sensitivity of the micrococci to u.v. radiation and, since it is a reducing agent, perhaps it protected an oxidation-reduction system.

Oxygen was shown to play a key role in sensitivity to u.v. radiation. There are two possible roles it might perform. (a) As a component of peroxide production. The production of peroxide(s) as an explanation for the lethal effect of u.v. radiation is ruled out for several reasons. No difference in catalase production between red and white micrococci was detected which might account for the different sensitivities. This agrees with the observations of Adler (1963) who found no correlation between resistance to ionizing radiation and catalase content in Escherichia coli mutants. The presence or absence of $\mathrm{O}_{2}$ at the moment of u.v. irradiation, which would be critical for u.v.-dependent peroxide production, had no effect upon the u.v. sensitivity of Micrococcus violagabriellae; and u.v. irradiation of the medium, even for twice the standard interval of time, did not make it toxic.

(b) The second possible role of $\mathrm{O}_{2}$ might be as a terminal acceptor in the cytochrome-linked electron transfer chain. This seems the most likely role of $\mathrm{O}_{2}$ since the substitution of another usable electron acceptor such as $\mathrm{NO}_{3}-$ for $\mathrm{O}_{2}$, completely restored the u.v. sensitivity of anaerobically-grown Micrococcus violagabriellae. This supposes that $M$. violagabriellae uses one metabolic pathway while growing anaerobically and a different pathway, sensitive to brief exposure to u.v. radiation, when growing in the presence of $\mathrm{O}_{2}$ or $\mathrm{NO}_{3}{ }^{-}$. The results of the experiments with $\mathrm{NaF}$ support this. Fluoride is a selective inhibitor of the glycolytic pathway, inhibiting enolase activity (Warburg \& Christian, 1942). Since fluoride did not inhibit either aerobic growth or pigment formation by $\boldsymbol{M}$. violagabriellae it is assumed that aerobic mechanisms were unaffected by the concentration used, and that glycolysis represented an insignificant fraction of the activity of the micrococci under aerobiosis. However, under anaerobiosis the micrococci must rely more heavily on the glycolytic mechanism and fluoride then becomes a potent inhibitor. The fact that both $\mathrm{O}_{2}$ and $\mathrm{NO}_{3}$ - functioned in the stimulation of growth, the annullment of fluoride inhibition, and the increase of u.v. sensitivity of the organisms, is evidence for the similarity of their roles.

It would appear then that the sensitivity of the organisms to short term exposure to $u . v$. radiation is associated with the presence in the micrococci, at the time of irradiation, of an iron dependent oxidation-reduction system which will use either $\mathrm{O}_{2}$ or $\mathrm{NO}_{3}^{-}$as a terminal electron acceptor. This might be a shared cytochromelinked electron transfer chain.

If Micrococcus violagabriellae is grown aerobically, or anaerobically in the presence of $\mathrm{NO}_{3}{ }^{-}$, the organisms will preferentially use the 'aerobic', that is, the more efficient cytochrome-linked system, and as a result be metabolically committed to a greater extent to this system than are their anaerobically grown counterparts. If the site of u.v.-radiation damage is somewhere along this path and if this mechanism is destroyed, then the aerobically grown micrococci have had a greater percentage of the metabolic machinery damaged, i.e. have suffered a larger lesion(s) with respect to total respiratory activity, and hence have a lower probability of recovery than anaerobically-grown micrococei which have not relied on that mechanism for a 
significant part of their activity. The protective and restorative effects of iron in this regard are obvious.

It has been observed that $\mathrm{O}_{2}$ and respiratory $\mathrm{NO}_{3}{ }^{-}$reduction share cytochromelinked pathways of electron transport in several micro-organisms (Taniguchi, Sato, \& Egami, 1956; Sadana \& McElroy, 1957) and that $\mathrm{O}_{2}$ tension of the medium can dictate the alternate route of terminal electron transfer used (Lenhoff, Nicholas \& Kaplan, 1956). Berliner (1963) showed that u.v. radiation produced reversible changes in luminescence (an electron transfer system) in the basidiomycete Armillaria mellea. This permits the hypothesis that sensitivity to u.v. radiation in Micrococcus violagabriellae is correlated with differences in electron transfer systems resulting from different growth conditions.

The effects of u.v. radiation on cell nuclear material have been extensively studied and established. It is not claimed that this damage does not occur in Micrococcus violagabriellae but rather that there is also a mechanism(s) involving electron transport which is susceptible to lower degrees of u.v. irradiation than those associated with damage to the deoxyribonucleic acid fraction. This agrees with the findings of Canzanelli, Sossen \& Rapport (1957) who showed that u.v. irradiation of rat liver mitochondria depressed succinoxidase and cytochrome oxidase activity, and that the energy necessary to effect such changes was much less than that necessary to produce chemical changes in nucleic acid derivatives. In $M$. violagabriellae it is solely with the 'cytochrome' site that the modifying effects exhibited by anaerobiosis, iron, etc., are associated. Examination of the survival curves shows that in all cases, the differences between red and white micrococci, aerobically- and anaerobically-grown micrococci, u.v.-irradiated micrococci placed in iron-containing and iron-deficient media, etc., are reflected in the response of the organisms to the first 10 sec. or so of u.v. irradiation. As the doses increased, in all cases the curves became essentially parallel, the differences being a reflexion of tolerance of the low dosage. At the higher dosage the nuclear sites, which are not affected by iron, $\mathrm{O}_{2}$ tension, etc., are irreversibly damaged and the modifying effect of the above mentioned parameters ceases.

This work was supported by grant number MA-1199 from the Medical Research Council of Canada (and in part by grant number A-1743 from the National Research Council of Canada). The authors would like to express their gratitude to Mrs E. Olasz, Miss Rita Elaschuk and Miss Sheila Berry for technical assistance in these investigations.

\section{REFERENCES}

AdLer, H. I. (1963). Catalase, hydrogen peroxide, and ionizing radiation. Rad. Res., Suppl. 3, 110.

Berliner, M. D. (1963). The action of monochromatic ultraviolet radiation on luminescence in Armillaria mellea. Rad. Res. 19, 392.

Campreli, J. N., Nichols, J. L. \& Berry, S. A. (1964). Characterization of the pigment of Micrococcus violagabriellae. Can. J. Microbiol. 10, 659.

Canzaneldi, A., Sossen, R. \& Rapport, D. (1957). Succinic and cytochrome oxidase activity of rat liver mitochondria after in vitro irradiation with ultraviolet light. Am. J. Physiol. 188, 547.

Cassingena, R., Ortali, A. V., Villa, L. \& Milazzo, M. (1960). Micrococcus violagabriellae (Castellani, 1955). Rend. Ist. Super. di Santá, 23, 1. 
Castellant, A. (1955). Note préliminaire sur un noveau micrococque isolé d'une dermatite axillaire superficielle tropicale. Ann. Inst. Pasteur, 89, 475.

Cohen-Baztre, G. \& Stanier, R. Y. (1958). Specific inhibition of carotenoid synthesis in a photosynthetic bacterium and its physiological consequences, Nature, Lond. 181, 250.

Duggan, D. E., Anderson, A. W. \& Elumker, P. R. (1963). Inactivation of radiationresistant spoilage bacterium Micrococcus radiodurans. I. Radiation inactivation rates in three meat substrates and in buffer. Appl. Microbiol. 11, 398.

Dundas, I. D. \& Larsen, H. (1962). The physiological role of the carotenoid pigments of Halobacterium salinarium Arch. Mikrobiol. 44, 233.

Fuller, R. C. \& ANDerson, I. C. (1958). Suppression of the carotenoid synthesis and its effect on the activity of photosynthetic bacterial chromatophores. Nature, Lond. 181, 252.

KASHKET, E. R. \& Brodie, A. F. (1962). Effects of near-ultraviolet irradiation on growth and oxidative metabolism of bacteria. J. Bact. 83, 1094.

Lenhoff, H. M., Nicholas, D. J. D. \& Kaplan, N. O. (1956). Effects of oxygen, iron and molybdenum on routes of electron transfer in Pseudomonas fluorescens. J. biol. Chem. 220, 983.

Mathews, M. M. \& Sistrom, W. R. (1959). Function of carotenoid pigments in nonpathogenic bacteria. Nature, Lond. 184, 1892.

Payne, J. I. \& Campbell, J. N. (1962). The influence of iron on pigmentation and resistance to ultraviolet irradiation in Micrococcus violagabriellae. Bact. Proc. p. 59.

Payne, J. I. \& Campbell, J. N. (1963). Concerning the site of ultraviolet sensitivity in Micrococcus violagabriellae. Bact. Proc. p. 50.

Pelczar, Jr., M. J. (Chairman) (1957). Manual of Microbiological Methods, pp. 153-154. New York: McGraw-Hill Co. Inc.

Pollock, M. R. (1946). Adaptation of 'nitratase' in washed suspensions of bacteria. Br. J. exp. Path. 27, 419.

Sadana, J. C. \& McElroy, W. D. (1957). Nitrate reductase from Achromobacter fischeri purification and properties: Function of flavines and cytochrome, Arch. Biochem. Biophys. 67, 16.

Sistrom, W. R., Griffiths, M. \& Stanier, R. Y. (1946). The biology of photosynthetic bacterium which lacks colored carotenoids. J. cell. comp. Physiol. 48, 473.

Taniguchi, S., Sato, R. \& Egami, F. (1956). The enzymatic mechanisms of nitrate and nitrite metabolism in bacteria. In Symposium in Inorganic Nitrogen Metabolism. Ed. by W. D. McElroy \& B. Glass, pp. 87-108. Baltimore: The Johns Hopkins Press.

Warburg, O. \& Christian, W. (1943). Isolierung und Kristallization des Gärungsferments Zymohexase. Biochem. Z. 314, 149. 